\title{
STATUS OF AGATHIS FLAVESCENS (ARAUCARIACEAE) IN PENINSULAR MALAYSIA
}

\author{
C.L. LIM \\ Forest Research Institute Malaysia, 52109 Kepong, Malaysia
}

SUMMARY

The narrowly endemic species Agathis flavescens Ridl., known only from altitudes between 1100 and $2100 \mathrm{~m}$ on Gunung Tahan and Gunung Rabong, Peninsular Malaysia, is reinstated as a distinct species.

Key words: Araucariaceae, Agathis, Gunung Tahan, Peninsular Malaysia.

\section{INTRODUCTION}

Agathis Salisb. is in Peninsular Malaysia represented by two species, A. flavescens Ridl. and A. borneensis Warb. Agathis flavescens, a montane species, is endemic on Gunung Tahan, the highest mountain in Peninsular Malaysia $(2187 \mathrm{~m})$ and nearby Gunung Rabong (1539 m). Ridley (1914) described it as new based on the size of the tree $(<21 \mathrm{~m})$ and the small size of the male cone. Furthermore, he noted that it was conspicuous on exposed mountain ridges due to the "curious yellow colour" of the tree crown. Whitmore (1980) reduced it to subspecific rank as A. dammara (Lamb.) Rich. subsp.flavescens (Ridl.) Whitmore on the grounds that it is sympatric with A. borneensis and that the shape and size of the male cone and microsporophyll of the two taxa are not different (Whitmore, 1980). He stated that careful observations on Gunung Tahan are necessary to elucidate its status (Whitmore, 1972) and speculated that A. flavescens is a high mountain form of A. borneensis (Whitmore, 1980). Later, on nomenclatural grounds, Veldkamp \& De Laubenfels (1984) transferred this subspecies to A. celebica (Koord.) Warb. subsp. flavescens (Ridl.) Veldkamp \& Whitmore. De Laubenfels (1988), however, treated A. flavescens as a species distinct from A. borneensis based on a wider range of characters, namely size of leaf, size and shape of the male cone and microsporophyll and the type of the basal lobe of the megasporophyll, but he gave no reason for the change. Farjon (2001) listed it as a distinct species.

The aim of this study is to reassess the characters used to separate these two taxa based not only on herbarium specimens but also on field observations of populations of both species on Gunung Tahan.

In the statistical analysis, only Peninsular Malaysian specimens with vegetative and reproductive structures ( 8 A.flavescens and 13 A. borneensis) were selected. Character states of 9 characters ( 7 quantitative and 2 qualitative) were recorded from the specimens. 
Each herbarium specimen was considered an individual Operational Taxonomic Unit (OTU). The computer program Multi-Variate Statistical Package (MVSP) version 3.10b was used to test the significance of the combination of these characters.

\section{IMPORTANT CHARACTERS}

Leaves

According to Whitmore (1980), the leaf is too variable and does not have any taxonomic value. De Laubenfels (1988) recorded a leaf size of 3-4 by 1-2 $\mathrm{cm}$ for A. flavescens and $6-12$ by $2-3.5 \mathrm{~cm}$ for A. borneensis. However, I found that although the figures for absolute length and width overlap, 3-5.5(-5.9) by (1-) $2.5-3 \mathrm{~cm}$ for A. flavescens and (4-)7.2-11.3(-14.5) by (2-)2.5-4(-5.5) cm for A. borneensis, the ratio of width to length effectively separates these two taxa. Agathis flavescens has an average ratio of 2.16 while that for A. borneensis is 3.10. In addition, the leaf apex of A. flavescens is rounded while that of the majority of A. borneensis is pointed.

Field examination confirm Ridley's 1914 observation that in totally exposed habitats, leaves of $A$. flavescens are distinctly glossy yellow, while in more shaded habitats, they are yellowish green. In contrast, those of A. borneensis are always dark glossy green.

\section{Male cones and microsporophylls}

Whitmore (1980) stated that for A.flavescens, the size of the male cone is c. 4 by 1 $\mathrm{cm}$ while that for $A$. borneensis is $5-9$ by $2-4 \mathrm{~cm}$. De Laubenfels (1988) gave the size of the male cones of $A$. flavescens as $2-3.5$ by $8-9 \mathrm{~cm}$ and $A$. borneensis as $4-7$ by $2-2.5 \mathrm{~cm}$. In the present study, male cones of A.flavescens measured (1.3-)2.4-2.7(-3) $\mathrm{cm}$ long and (0.8-)1-1.2 cm wide and those of A. borneensis $(3-) 3.9-6.9(-8.6) \mathrm{cm}$ long and (1.7-)1.8-2.3(-2.9) $\mathrm{cm}$ wide. Cone width is therefore a reliable character for separating these two taxa.

Microsporophylls of the two species differ in both size and shape (Fig. 1). Microsporophylls of $A$. flavescens are smaller and shorter, (1.9-)2.8-3.1 by (1.3-)1.6-2.5(-3) mm, compared with those of A. borneensis, (6-)7.2-8.5(-9.9) by (3-)4-6(-7) mm. The shape of the apex is also different: helmet-shaped in A.flavescens compared with spoon-shaped in A. borneensis.

Furthermore, field observations and herbarium specimens showed that a pair of leaflike bracts below the cone of A. flavescens is a constant character that is not seen in A. borneensis. This important character was not mentioned by De Laubenfels (1988).

\section{Female cones and megasporophylls}

De Laubenfels (1988) distinguished the taxa by the presence and shape of the lobes at the base of the megasporophyll: Agathis flavescens has two rounded lobes while A. borneensis has only a sharply angled lobe. However, based on the specimens collected from the field, this character is neither consistent nor distinct (Fig. 1) because the shape and size of the megasporophyll differ greatly in a single cone depending on its position within the cone. 

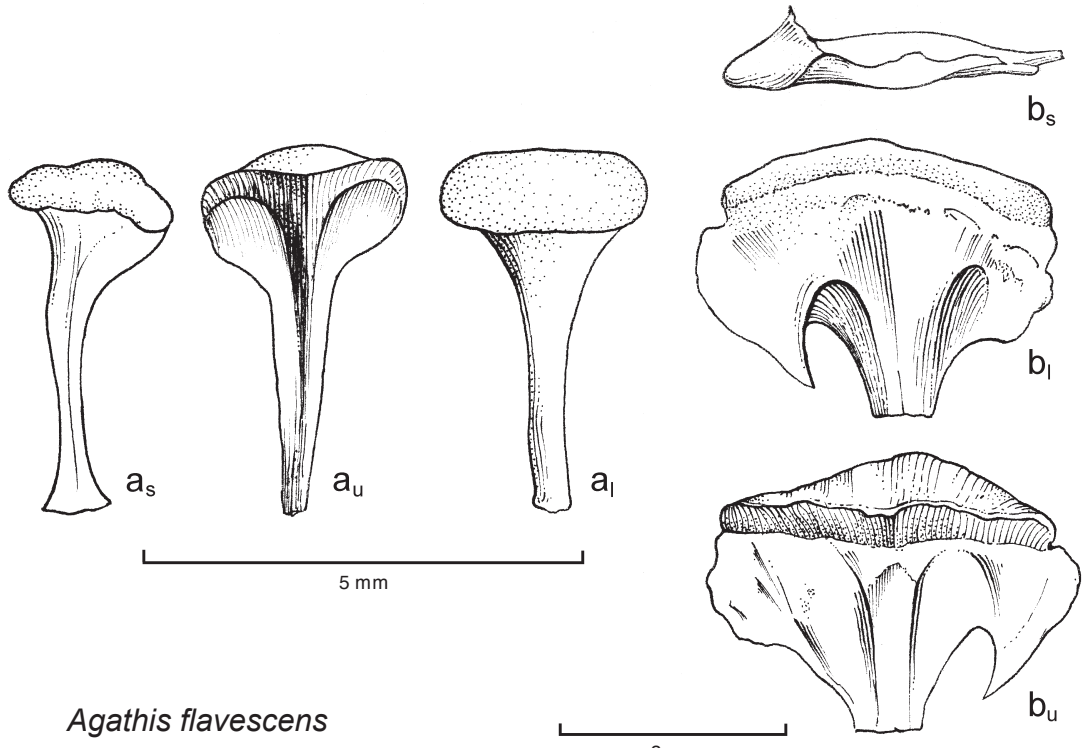

Agathis flavescens

$2 \mathrm{~cm}$
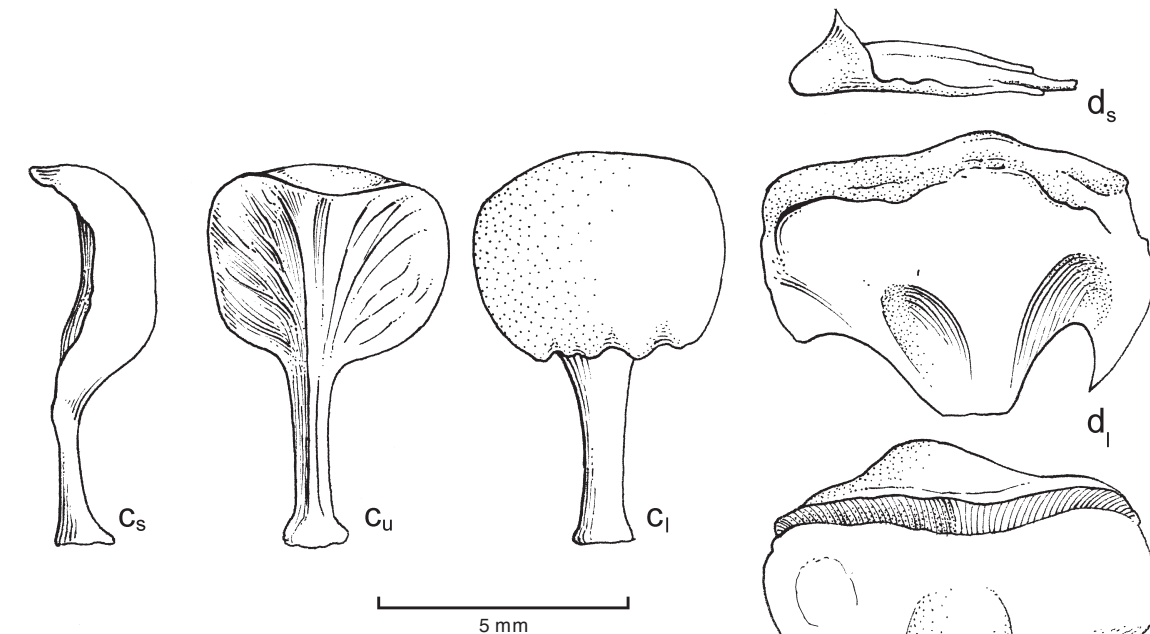

Agathis borneensis

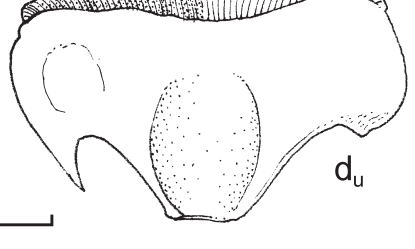

Fig. 1. Microsporophylls and megasporophylls. — a, b: Agathis flavescens Ridl. a. Microsporophylls; b. megasporophylls. - c, d: A. borneensis Warb. c. Microsporophylls; d. megasporophylls. $\mathrm{l}$ = lower surface, $\mathrm{u}=$ upper surface, $\mathrm{s}=$ side view (a: Lim FRI 56315; b: Corner SFN 33690; c, d: Lim FRI 56476). Drawn by Zainal Mustafa. 


\section{Habitat}

Two populations of $A$.flavescens were studied on Gunung Tahan: one on the northwest side at $1500 \mathrm{~m}$ (near Berlumut Camp, 4 38' 24.6" N, $102^{\circ} 11^{\prime} 47.6^{\prime \prime} \mathrm{E}$ ) and the other on the south side at 1633 m (near Gunung Reskit 4 $4^{\circ} 35^{\prime} 52.5^{\prime \prime} \mathrm{N}, 102^{\circ} 15^{\prime} 29.3^{\prime \prime} \mathrm{E}$ ). Agathis borneensis grows on the north-west side at $698 \mathrm{~m}$ (Kor Camp, 4 39' 05.5" N, $\left.102^{\circ} 10^{\prime} 34.7^{\prime \prime} \mathrm{E}\right)$ and at $1099 \mathrm{~m}$ on the south side near Pondok Dua Belas Camp $\left(4^{\circ} 34^{\prime} 28.7^{\prime \prime} \mathrm{N}, 102^{\circ} 16^{\prime} 39.7^{\prime \prime} \mathrm{E}\right)$ and at $575 \mathrm{~m}$ on Gunung Rajah (4 30' 28.4" N, $\left.102^{\circ} 21^{\prime} 16.2^{\prime \prime} \mathrm{E}\right)$. Although they are reported as sympatric on Gunung Tahan, the populations of the two taxa do not actually overlap but are separated by altitude. Agathis flavescens is found at the altitude above $1500 \mathrm{~m}$ while A. borneensis is found below $1100 \mathrm{~m}$. Ridley's observation that A. flavescens is a smaller tree is correct, it grows up to about $21 \mathrm{~m}$ in height while A. borneensis can reach $50 \mathrm{~m}$.

\section{CONCLUSIONS}

In addition to the characters used by De Laubenfels (1988) (namely a combination of leaf size, leaf apex, shape and size of the male cone and microsporophyll), the pair of bracts below the male cone, tree height and their altitudinal range are also important characters to distinguish the two taxa. Analysis using MVSP show conclusively that A. flavescens is clearly distinguished from A. borneensis by combination of these characters (Fig. 2). However, characters of the megasporophyll are not useful. Therefore, A. flavescens warrants species status.

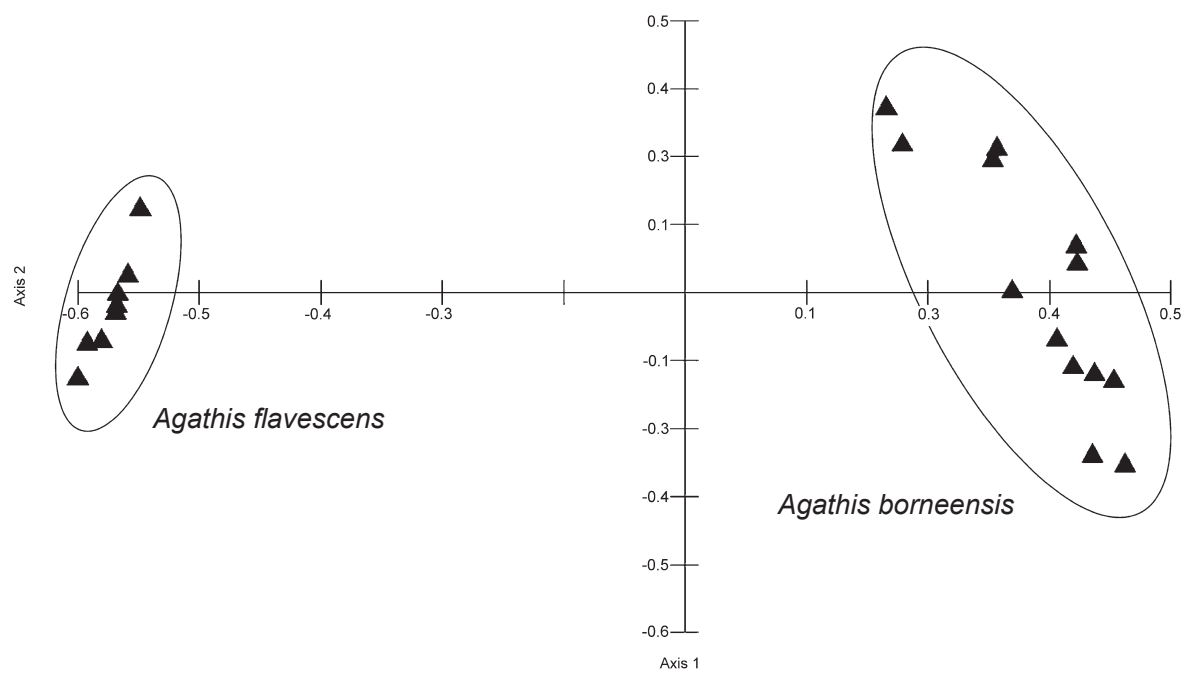

Fig. 2. Differentiation of Agathis flavescens Ridl. and A. borneensis Warb. using Principal Coordinates analysis using Pco case scores (Gower General Similarity Coefficient). Characters included in the analysis: Leaf (apex, length and width), male cone (length and width), microsporophyll (length), microsporophyll head (shape, length and width). 


\section{Agathis flavescens Ridl.}

Agathis flavescens Ridl. (1914) 332, (1915) 196, (1925) 278; Meijer Drees (1940) 464; Whitmore (1972) 43, f. 1; De Laubenfels (1988) 438, f. 70. - Agathis dammara (Lamb.) Rich. subsp. flavescens (Ridl.) Whitmore (1980) 59. - Agathis celebica (Koord.) Warb. subsp. flavescens (Ridl.) Veldkamp \& Whitmore (1984) 346. - Type: Ridley 16023 (holo K; iso SING), Peninsular Malaysia, Pahang, Gunung Tahan.

Distribution - Endemic in Peninsular Malaysia; recorded only from Gunung Tahan, Pahang, and Gunung Rabong, Kelantan.

Specimens examined:

Peninsular Malaysia. Pahang, Gunung Tahan: Corner SFN 33690 (K, L, SING); Lim FRI 56315 (KEP); Md. Hanif \& Md. Nur SFN 7981 (SING); Ng FRI 1498 (KEP), FRI 20911(KEP), FRI 20921 (KEP); Ridley 16023 (K, SING); Soepadmo 973 (K, KEP, KLU, L, SING); Whitmore FRI 4870 (KEP), FRI 4897 (KEP), FRI 20682 (KEP); Wong \& Wyatt-Smith W 72 (KEP), W 153 (KEP), W 172 (KEP); Wray \& Robinson 5488 (K, SING). Kelantan, Gunung Rabong: Soepadmo \& Mahmud 1150 (K, KEP, KLU, L, SING); Whitmore FRI 20671 (KEP), FRI 20673 (KEP).

\section{ACKNOWLEDGEMENTS}

This research was carried out as part of the Flora of Peninsular Malaysia Project (Project number: 01-04-01-0000) at the Forest Research Institute Malaysia funded by the Ministry of Science, Technology and Innovation. I am grateful to the curators of the K, KLU, L and SING herbaria for permission to examine specimens in their care. I thank Dr P. Wilkie, H.L. Kueh and A. Mohd. Nazri for the help in the field, Dr R. Kiew for editorial comments and Dr L.G. Saw for advice on statistical analysis.

\section{REFERENCES}

De Laubenfels, D.J. 1988. Coniferales. Flora Malesiana, Ser. I, 10: 429-439.

Farjon, A. 2001. Araucariaceae. World checklist and bibliography of Conifers, 2nd ed. Roy. Bot. Gard., Kew.

Meijer Drees, E. 1940. The genus Agathis in Malaysia. Bull. Jard. Bot. Buitenzorg III, 16: 464466.

Ridley, H.N. 1914. Agathis flavescens. Kew Bull.: 332.

Ridley, H.N. 1915. The botany of Gunong Tahan, Pahang. J. Fed. Malay States Mus. 6: 196-197.

Ridley, H.N. 1925. The Flora of the Malay Peninsula 5. Reeve \& Co., Ashford, Kent.

Veldkamp, J.F. \& D.J. de Laubenfels. 1984. Proposal to reject Pinus dammara (Araucariaceae).

Taxon 33: 337-347.

Whitmore, T.C. 1972. Tree Flora of Malaya 1. Longman, London.

Whitmore, T.C. 1980. A monograph of Agathis. Pl. Syst. Evol. 135: 41-69. 